Historic, Archive Document

Do not assume content reflects current scientific knowledge, policies, or practices. 



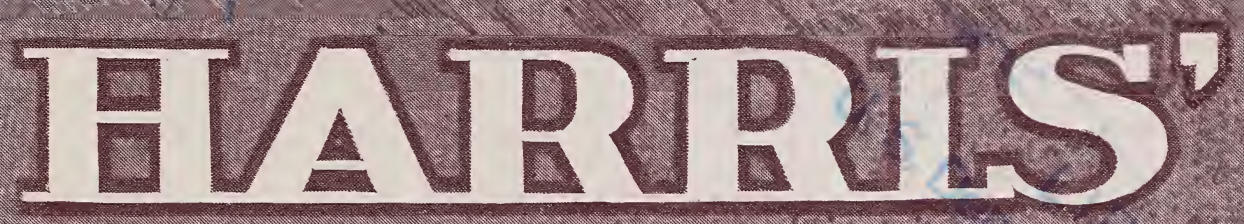

FaTI CATALOGUE

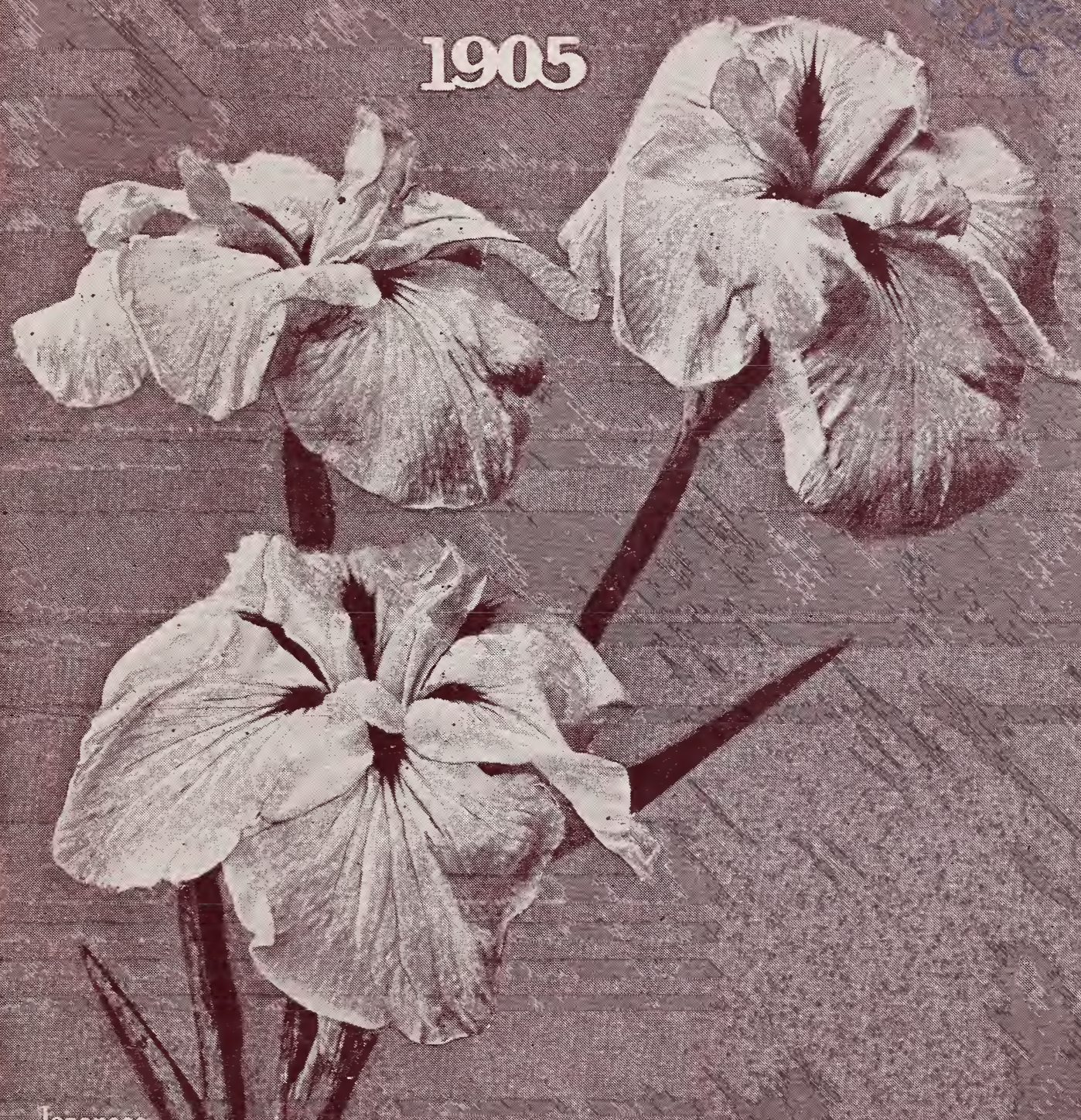

dapancse






\section{PRICES OF BULBS.}

Practically all so-called Dutch Bulbs are imported from Holland, where they grow to the greatest perfection. Prices in Holland are, of course, much lower than in this country, and we find that we can import the very best bulbs from the largest growers in Holland at prices which make it possible to sell them at considerably lower prices than are usually charged in this country. We have, therefore, imported a lot of choice bulbs, and offer them to our regular customers at the low prices quoted in this catalogue. Please compare with prices charged by other dealers.

\section{ABOUT ORDERING, SHIPPING, ETC.}

When to Order.-Bulbs will be ready for delivery the latter part of September, but orders may be sent at any time before or after that date, and the bulbs will be sent when they are ready, or when it is time to plant them.

How Bulbs and Plants are Shipped.-When ordered in any considerable quantities, bulbs and plants will be sent by express. Small quantities of some bulbs can be sent by mail if the postage is added to the price quoted. When bulbs are quoted at so much each, they will be mailed at that price without extra charge.

Express Charges are in all cases to be paid by the purchaser. To places having either the American, Adams, United States, National, or Wells-Fargo express, a collection of 400 or 500 bulbs could be sent for about $35 \mathrm{c}$, if the distance is not more than $\mathrm{I}, 000$ miles. To places near by a larger number of bulbs or plants could be sent for the same amount. Bulbs and plants are carried at special low rates the same as seeds.

Order Early.-By sending your order in early you will be sure of getting the kinds and varieties of bulbs and plants you want, which may be sold out later. If the order is sent late, please state whether we shall send some other similar variety if sold out of the one ordered, or return the money sent.

Hardy Perennial Plants will not be ready to transplant until the middle of October. When these as well as bulbs are ordered, the bulbs will be held until the plants are ready, unless we are otherwise instructed.

Our address is

\section{JOSEPH HARRIS CO.,}

Moreton Farm, Coldwater, N. Y.

We ship from Rochester, when better express and freight rates can be obtained, without extra charge. 


\section{ORDER SHEET \\ JOSEPH HARRIS CO.}

Moreton Farm, Coldwater, N. Y.

Name

Amount of

Money Sent.

\section{Post Office}

County

State

Express or Freight Station.

Directions for Shipping ( $\begin{aligned} & \text { Please state on this line whether you wish the } \\ & \text { articles ordered sent by mail, express or freight }\end{aligned}$ )

Date. 1905 



\section{FLOWERS IN EARLY SPRING.}

Is there anything more cheering after a long winter than to see the crocuses, tulips and daffodils pushing up through the ground before the snow has hardly gone, and a little later to see their bright and charming flowers. blooming so freely before other plants have thought of starting into life?

We notice that very few country homes have as many of these spring flowers as they should. The first cost of the bulbs is small and it is practically no trouble to plant them and they will last for years with no attention whatever.

Take crocuses for instance; why not have small groups of these little flowers scattered about the lawn, among the shrubs, under the trees and in out of the way corners? You can get 500 bulbs for $\$ 1.50$ and think how pretty they would look flowering in the early spring; crocus bulbs planted in the grass will last for years and the grass may be cut as early as necessary without injuring them in the least.

But while crocuses are very pretty it remains for tulips and narcissus or daffodils, which bloom a little later, to add the real charm to the grounds in the early spring. What a really beautiful effect can be produced by a mass of tulips of nearly even height and harmonious colors can hardly be understood by those who have not seen the best varieties skilfully used. We do not mean by this that tulips should be planted in beds composed of rows of different colored flowers, though this is a popular method. What we do mean is that varieties that harmonize in color and flower at the same time should be used in groups by themselves instead of a lot of mixed varieties being planted together. (We offer some suggestions as to what varieties to use under the head "Tulips" in this catalogue.)

Daffodils and Narcissus are at their best when growing in the grass or in any out-of-the-way place when they are not disturbed for years, as they increase in size and beauty as they get older. There are many places around any country house where these charming flowers would add greatly to the beauty of the grounds. They should be planted where the grass is not cut until about July Ist, because if the tops are cut off earlier the bulbs do not properly mature. There are many beautiful varieties that are little known and should be more generally planted.

There are two or three other hardy flowers grown from bulbs that are not as well known as they should be. Chionodoxa ("Glory of the Snow") blooms as eariy as the snowdrops and its charming blue and white flowers make a very pleasing contrast to the snowdrop's white ones (see page ro). Milla Uniflora is another little known spring flowering bulb that ought to be largely planted. It should be planted in rather moist soil where it can remain without being disturbed. It will soon cover the ground and its white star-like flowers are producers in great numbers and are extremely pretty.

All these bulbs must be planted in the FALL. They will not amount to anything if planted in the spring. 


\section{FLOWERS IN WINTER.}

It is quite a simple matter to raise Hyacinths, Narcissus and Tulips in the house during the winter and they will well repay for the little trouble

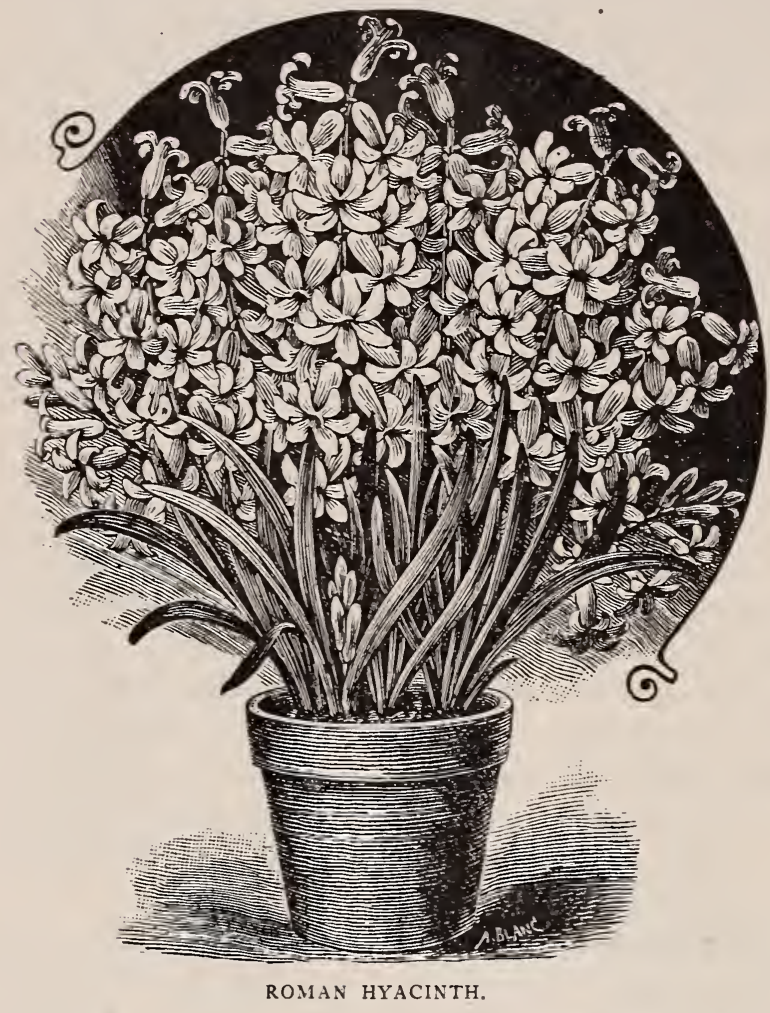

it is necessary to give them.

Hyacinths. The easiest variety to force and the earliest to flower is the Roman Hyacinth, having small white flowers of delicious fragrance. The bulbs may simply be placed in a glass containing water and a few pebbles, but the better way is to put them in pots, pans or boxes containing some rich sandy soil. The bulbs should be planted close together and covered so that the top of the bulb is level with the soil. After thoroughly wetting the soil place the pots or other vessel containing the bulbs in a dark, cool place until the bulbs get well rooted and start to grow, when they may be brought into the light, but it is best to keep them quite cool until nearly in flower. These Hyacinths can be started in October and the flowers will be out in January.

Dutch Hyacinths can also be grown in the house as readily as the small Roman variety but they do not flower as early, and the spikes of flowers are larger than those of the Roman. They should be left in the cellar until about February Ist: Narcissus, Daffodils and Tulips can easily be grown in the house by giving the same treatment as suggested above for Hyacinths. They should however, not be brought into a warm room before March ist.

The point to be remembered when attempting to raise flowers from bulbs in the house is that the bulbs must be well rooted in the pots or boxes before they are brought into the light and warmth. If they are allowed to root in a low temperature $\left(40^{\circ}\right.$ to $\left.50^{\circ}\right)$ they will produce strong shoots and fine flowers when brought into a warm, light room. 


\section{CROCUS.}

With the exception of snowdrops the crocus is the first flower we see in the spring, and for this reason if for no other it should be planted in liberal quantities on every lawn Simply make a little hole in the sod, in the fall, and press the bulb in so that it is covered with about an inch of earth. Once planted they will flower for many years and you will welcome with joy their first appearance in the spring.

In setting out the bulbs it is much better to plant them in irregular groups, using 25 to 50 bulbs in a place than to scatter them singly over the whole lawn. They are very effective planted among shrubbery, under trees and in any corner of the lawn or garden. They are also useful to plant in beds of tulips and other late flowering bulbs as they flower early and are gone before the other flowers come on.

We offer a few of the handsomest large flowering varieties which are far superior to the ordinary mixed crocus usually sold. By grouping each variety by itself a very pleasing effect is produced.

Cloth of Gold-Golden yellow striped with dark brown ........... \$ . 10 \$.60

Miss Mina-Light blue and white striped early and very fine........... .

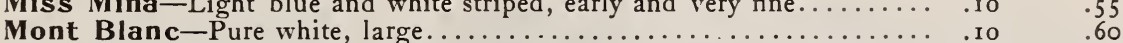

Sir John Franklin-Deep purple, handsome.................. .

Sir Walter Scott-Violet and white striped, very handsome........ . Io $\quad .55$

Mammoth Yellow-Largest pure yellow flowers, first size bulbs....... $\quad .12 \quad .85$

Yellow-Second size bulbs............................... . 10 60

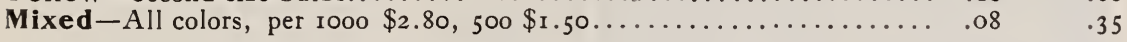

Note-If the bulbs are to be sent by mail add $5 \mathrm{c}$ per 100 for postage. Dozens deliverd free.

\section{SNOWDROPS.}

The first flower to bloom in the open ground in the spring. They are very pretty when planted in masses under trees or shrubs. They will last for many years and increase in number all the time.

Giant Snowdrop - The largest and finest variety, white flowers, per dozen, I2c; 100, $75 \mathrm{c}$.

\section{HYACINTHS.}

While mixed hyacinths are very good for outdoor planting they are not suitable for forcing in the house. Even in the open ground much finer results can be obtained by using the named varieties than by planting mixed bulbs as the spikes are larger and they are of uniform color and height.

The bulbs should be set out about 6 or 8 inches apart and deep enough so that they will be covered with 3 or 4 inches of earth. While the bulbs are hardy a covering of leaves or coarse manure after the ground freezes is very beneficial. This covering should be removed as soon as the snow goes in the spring.

Roman Hyacinth-For forcing in the house; small white flowers of delicious fragrance; flowers very early; not suitable for outdoor planting; bulbs, $6 c$ each; dozen $60 c$ (by mail 65 ); $100 \$ 4.50$.

Miniature Hyacinth-These small Dutch hyacinths are excellent for forcing and will flower in January, if started in October and November. We offer four separate colors; pure white, pink, light blue and dark blue. Bulbs, each $5 \mathrm{c}$; dozen $40 \mathrm{c}$; (by mail $50 \mathrm{c}$ ). $50 \$ 1.50 ; 100 \$ 2.75$.

\section{MIXED BEDDING HYACINTHS.}

These bulbs are all of large size and we offer them in separate colors so the that best effects can be produced. They are all single varieties. Double Hyacinths are so inferior for all purposes that we do not offer them.

We offer the following colors separate:

Rose pink, pure white, yellow and light blue-Bulbs $5 \mathrm{c}$ each; doz. $40 \mathrm{c}$ (by mail 50c); $100 \$ 3.00$ 


\section{NAMED VARIETIES OF BEDDING HYACINTHS.}

We have selected a few of the very best named varieties of Hyacinth suitable for beds where distinct colors and uniform height are desired. A very pleasing effect is produced by planting each variety by itself or in separate rows. All these varieties have very large, compact and symmetrical spikes of flowers and are the handsomest Hyacinths grown.

\begin{tabular}{|c|c|c|c|}
\hline & each & dozen & 50 \\
\hline General Pelessier-Bright red, very hand & .08 & $\$ .70$ & $\$ 2.20$ \\
\hline Giganthea-Very large spikes of rose pink flowers.. & .08 & .70 & 2.20 \\
\hline Grand Monarque-Light blue, fine............... & .08 & .70 & 2.20 \\
\hline King of the Yellows - Best yellow variety.......... & .08 & .70 & 2.30 \\
\hline La Grandesse-Pure white, beautiful. & .08 & .75 & 2.60 \\
\hline Leonidas-Rich deep blue. & .08 & .70 & 2.20 \\
\hline des Belges-Dark re & .08 & .70 & 2.20 \\
\hline
\end{tabular}

Note-If to be sent by mail add Ioc per dozen for postage.

\section{TULIPS.}

There is a great difference in varieties of Tulips and it will well repay any one to take some pains to get the kinds best suited to their purpose and to plant them so that they will appear to the best advantage. It is not a good plan to set out early and late or tall and

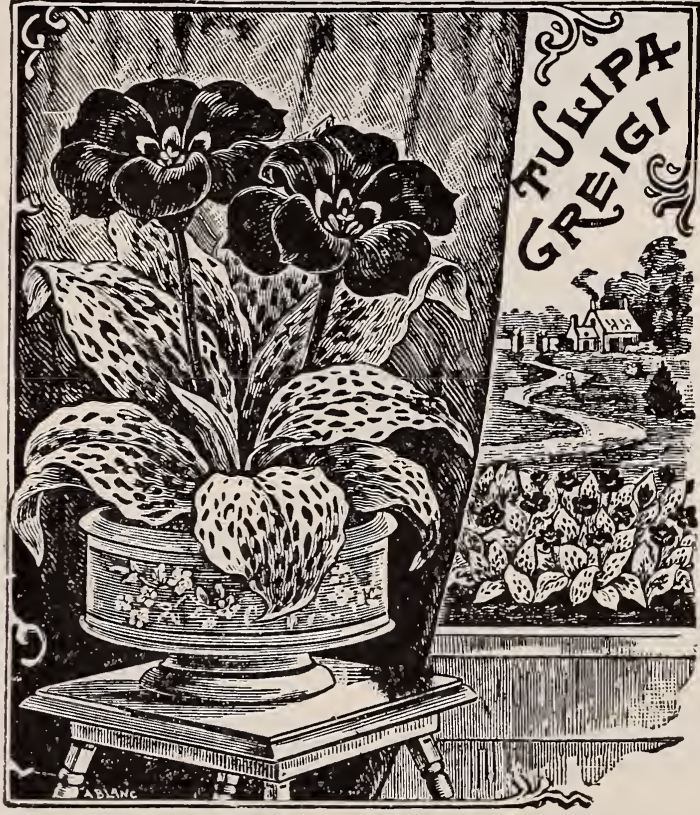

Single Tulip Greigi. short varieties together. In either case the effect is poor. Tulips look best in groups or masses of the same color or of two contrasting colors but of the same height and general appearance. These results cannot be obtained by the use of ordinary mixed Tulips. Named varieties should always be used when the best effects are desired. We have taken a good deal of pains to select the very handsomest varieties of the different classes of Tulips and we are sure that all who plant bulbs of any of the named varieties we offer will be pleased with the results next spring. The mixed Tulips we offer are fully equal to any mixed varieties attainable and they will produce a brilliant display of flowers of many colors which are interesting and attractive.

By planting early single, early double, and late flowering Tulips each in groups by themselves a constant display of flowers may be had from the last of April until June.

\section{SUgGestions about PLANTING, Etc.}

Tulips should not be planted in grass which is cut early in the season as this will ruin the bulbs, but they will do well for two or three years in grass that is not cut until July and which does not grow too thick. Of course they can be planted in beds and the bulbs may be removed when the flowers are gone but the bulbs must be replanted in some out of the way corner of the garden so that they may mature and ripen before they are taken up and dried. If carefully transplanted with all the leaves left on the bulbs will not be injured and will produce good results the next season. Bulbs that have been taken up and dried before their leaves have died down will not produce good results and should not be used. If possible it is best to leave the bulbs undisturbed from one year to another but of course this is not practicable where the beds are to be used for other later flowers.

Tulip bulbs may be planted any time after October first until the ground freezes, but the earlier they are planted in October the better. The bulbs should be set about 5 or 6 inches apart and covered with 2 inches of earth. 


\section{SINGLE EARLY TULIPS.}

These varieties bloom very early and grow about 8 inches high. They are very handsome when grown in beds and borders or planted along the sunny side of the house. They are also the best varieties for forcing.

We offer a few of the most desirable varieties.

Chrysolora-(9 in. high.) Pure yellow, large flowers and fine for

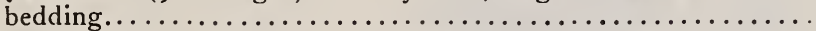

Cottage Maid-( 9 in.) White, edged with rose color, very

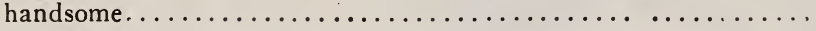

Duchesse de Parma-( 9 in.) Scarlet, edged with orange, producing an orange-scarlet effect which is very pleasing...........

Greigii-A new variety with very large flowers of a most beautiful shade of bright orange scarlet. The petals are unusually large and of a peculiar form with black spots at the base. The leaves

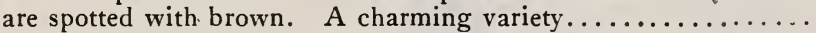

Pottebakker- $(9$ in.) Yellow and red variegated. Very showy,

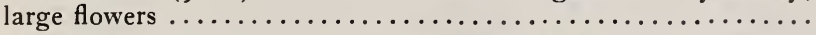

Pottebakker White- $(9$ in.) The best pure white of this class for

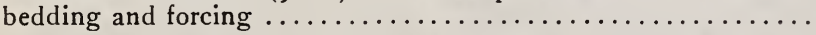

Pottebakker Scarlet-( 9 in.) Very handsome, bright scarlet...

Rose Luisante-( 8 in.) Rose color, veined and edged with white; flowers large and of fine form. A beautiful tulip, a little later

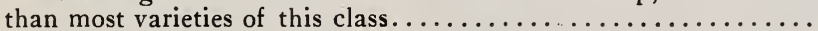

Vermilion Brilliant-A deep, glowing vermilion-a rich and beautiful color. One of the very finest red varieties, especially



Yellow Prince-(8 in.) Pure yellow, early, and excellent for forc-

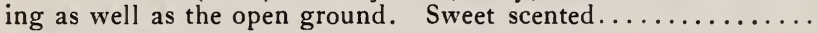

Mixed Colors - A mixture of many beautiful colors..............

$\begin{array}{rr}\text { dozen } & 100 \\ .20 & \$ 1.25 \\ .20 & 1.00 \\ & 1.10 \\ 1.10 & 8.00 \\ .20 & 1.25 \\ .25 & 1.50 \\ .30 & 2.00 \\ & \\ .60 & 4.25 \\ & \\ .55 & 4.00 \\ .20 & 1.00 \\ .15 & .80\end{array}$

Note-If Tulip bulbs are to be sent by mail add $3 \mathrm{C}$ per dozen or ${ }_{5} \mathrm{C}$ per 100 for postage. We will furnish 25 each of four varieties or 50 bulbs of one variety at the Ioo rate.

\section{VARIETIES FOR BEDDING.}

If you want a bed or border composed of red and white Tulips the best varieties to use are Pottebakker White and Pottebakker Scarlet. These are both of the same height and flower the same time. If you wish to add a yellow to these use Chrysolora.

\section{SINGLE LATE TULIPS.}

These are very handsome for bedding. The flowers are large and are borne on long stems and last a long time in bloom. In this latitude they flower about the middle of May.

Bouton d'Or-A beautiful golden yellow, large and of handsome

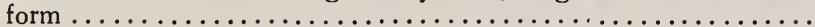

Gesneriana (Scarlet.)-One of the most effective Tulips for bed$\begin{array}{cc}\text { dozen } & \text { 100 } \\ \$ .30 & \$ 1.85\end{array}$ ding. The flowers are of the largest size and of an intensely brilliant scarlet, which does not fade but remains at its best for a long time. This variety and Bouton d'Or planted together are

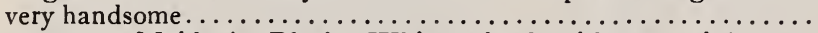

Picotee, or Maiden's Blush-White, edged with rose pink, very

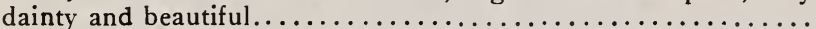

Parrot Tulin The flowers are beautifully cut and fringed, The flowers are beautifully cut and fringed,
which gives them a very distinct appear$\$ .30-\$ 1.85$

$\begin{array}{ll}.25 & 1.60 \\ .35 & 2.50\end{array}$
ance. The colors are yellow and red in various combinations and markings. We offer a mixture of the handsomest varieties, all with very large and beautifully colored flowers..............

Bulbs by Mail If only a few bulbs are wanted they can be sent by mail Bulbs by Mail with little extra expense. But the necessary postage must be added to the price of the bulbs. On Tulip bulbs the postage amounts to $3 \mathrm{c}$ per dozen or $15 \mathrm{c}$ per roo. If you want the bulbs sent by mail be sure to add the postage or there will be trouble and delay in filling the order. 


\section{DOUBLE TULIPS.}

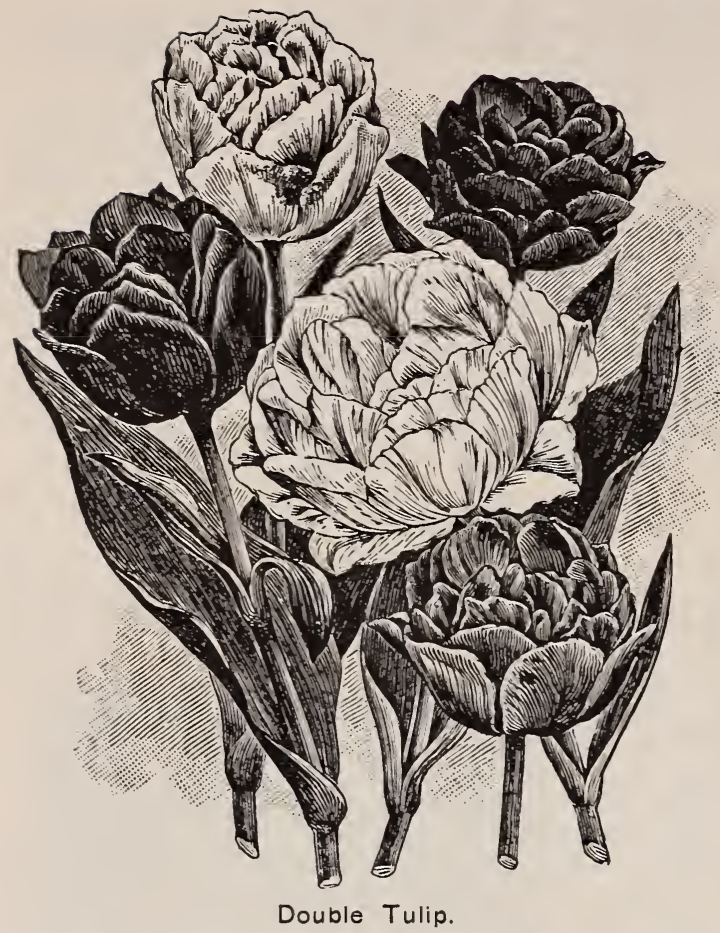

For some reason Double Tulips do not seem to be used as much as they deserve. The best varieties are undoubtedly tbe handsomest Tulip grown and are well worth the extra cost of the bulbs. They are not only very handsome flowers but they have the additional merit of remaining in bloom much longer than the single kinds.

A bed composed of but one variety, such as Tournesol or Leonardo da Vinci, will present a most gorgeous display of color for almost three weeks.

As most of the Double Tulips only grow 8 or 10 in. high they are suitable for planting in front of shrubs and other taller plants, where their brilliant colors will add greatly to the beauty of any lawn, especially as they flower early before other plants have come into bloom.

The varieties called $\mathrm{Mu}$ rillo and Tournesol are excellent for forcing in the house.

La Candeur-( 8 in. high). Pure white and of beautiful form. The finest white tulip............................................... $\$ 10$

Leonardo da Vinci-( 8 in.) Immense flowers of a deep red bordered with orange yellow. A bed of these tulips is a gorgeous sight. The

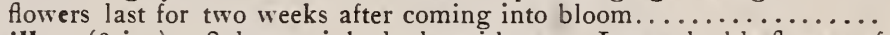

Murillo-(8 in. $)$. Salmon pink shades with rose. Large double fowers of beautiful form. Flowers early and is easily forced in the house. A beautiful variety.......................................... $\$ 3$.

Rex Rubrorum - (8 in.). Bright scarlet, large and full, very brilliant. This and La Candeur (white) go well together as they are of same

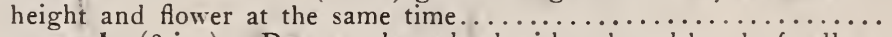

Tournesol- $(8$ in.). Deep scarlet, edged with a broad band of yellow. An extremely handsome and showy tulip and one of the finest varities for bedding or forcing, although it flowers early it remains in

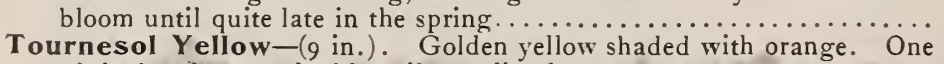

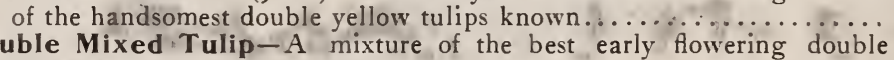
doz. 100 $.45 \quad 3.25$ $.25\} 1.80$ $.30 \quad 2.00$ .453 .00

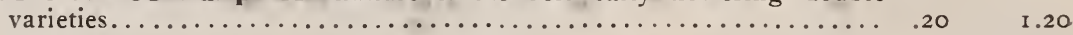
If the bulbs are to be sent by mail add 36 per dozen or $15 \mathrm{C}$ per 100 for postage.

\section{NARCISSUS or DAFFODILS.}

The name Daffodil is commonly applied to the varieties of Narcissus that have large yellow flowers with "trumpet" centers. Other varieties are called by the proper name for the whole class, Narcissus.

The Narcissus is a flower of many varieties and forms, many of which are among the handsomest of the hardy spring flowering bulbs. They start so early in the spring that they often push up through the snow and their charming flowers appear before any others of much importance have dared to put forth a bud. They are all perfectly hardy and will take care of themselves if left undisturbed, and increase in size and number as the years go by. 
If you have a spot of waste land in the corner of the lawn or garden you cannot do better than to fill it with Narcissus. Plant them in clumps of different varieties keeping each kind grouped by itself. They may be planted in the shade or among shrubs and in grass, but care should be taken not to put them where the grass is to be cut earlier than July ist. Their tops must have time to mature or the bulbs will be destroyed.

Among "Daffodils" we would especially recommend the single varieties, Emperor, Empress and Golden Spur. While these kinds resemble the common double Daffodil, Van Sion, they are larger and much handsomer and will be a delight to those who plant largely of them.

All varieties of Narcissus may be readily grown in the house. The best varieties for this purpose are Poeticus Ornatus, Polyanthus varieties (bloom very early), Van Sion (double), and Golden Spur (single). The last two varieties should not be forced too early. They should be kept in a dark, cool place after planting until about February rst, when they may be brought into a warm room and will flower in about 3 weeks.

\section{SINGLE NARCISSUS or DAFFODILS.}



Narcissus Emperor.

Emperor-A magnificent "trumpet" Daffodil, the largest and handsomest variety we have ever grown. The petals are light yellow and the "trumpet" deeper yellow. Far larger and handsomer than the common Daffodil, and grows on longer stems. Should be in every garden. Each, 6c; dozen, 40c (by mail 50c); 100, $\$ 2.00$.

Empress-Large flowers like Emperor but the petals are pure white and the "trumpet" is bright yellow. A very beautiful flower. Each, 6c; dozen, 45c (by mail 55c); 100, $\$ 2.85$. 
Barri Conspicua-Large primrose colored flowers with center crown of orange scarlet. A very handsome variety that should be better known and largely planted. It is the admiration of everyone who sees it. Bulbs, $5 \mathrm{c}$ each; dozen, $20 \mathrm{c}$ (by mail 25c), I00, \$1.25.

Golden Spur-Both petals and trumpet are of a deep golden yellow. Flowers of largest

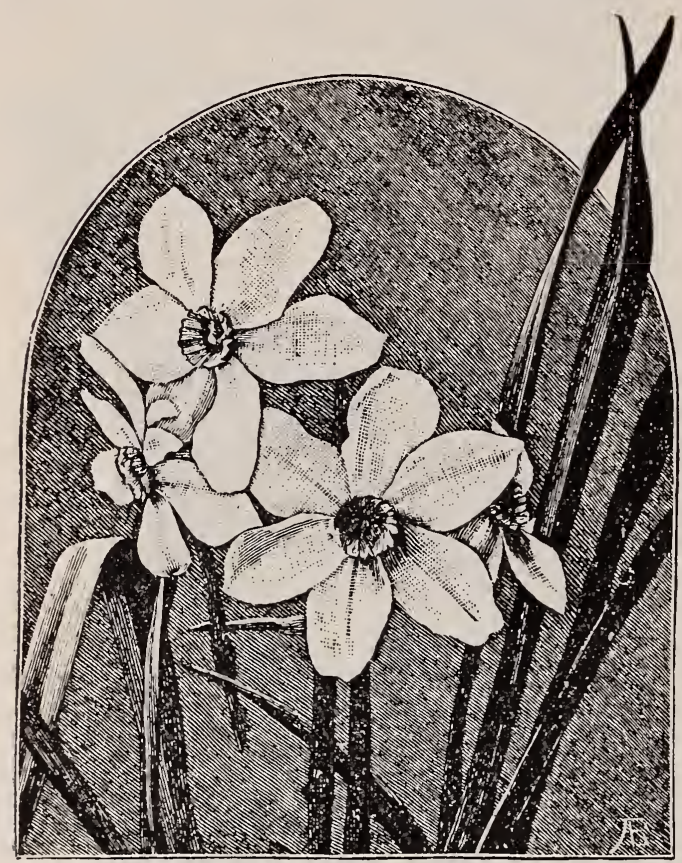

Narcissus Poeticus Ornatus. size and beautiful form. One of the very finest varieties of daffodils in cultivation. Each, $5 \mathrm{c}$; dozen, $45 \mathrm{c}$ (by mail $55 \mathrm{c}$ ); IOO, $\$ 2.75$.

Poeticus (Pheasant's Eye or Poet's Narcissus) - This is the well-known small white, sweet scented Narcissus. They will grow anywhere and take care of themselves when once planted. The flowers are about two inches in diameter; pure white with a small yellow cup in center, edged with red. They are very graceful and pretty, Dozen, I $5 \mathrm{c}$ (by mail I 7c); 100, $75 \mathrm{c}$.

Poeticus Ornatus - This is an early variety of Poeticus. Excellent for forcing and open ground. As this kind blooms earlier than the old variety it is well to have both. Dozen, I $5 \mathrm{c}$ (by mail I7c); I00, $85 \mathrm{c}$.

Jonquils (Campernelle)-Yellow, sweet scented flowers, 4 or 5 on a stem. Dozen, ${ }_{5} \mathrm{C}$ (by mail $\mathrm{I}_{7 \mathrm{c}}$ ); 100, $85 \mathrm{c}$.

Jonquil Rugulosus-An improved yellow Jonquil with large flowers of a deeper yellow, deliciously scented. Dozen, I5c (by mail I7c); 100, \$1.00.

\section{DOUBLE VARIETIES OF DAFFODILS.}

Orange Phoenix-One of the most beautiful double Daffodils. The flowers are large and full, white with orange center. Fine for forcing as well as out-door planting. Each, 4c; dozen, $30 \mathrm{c}$ (by mail 35c); IOO, $\$ \mathrm{r} .85$.

Poeticus albo pleno-A double form of Poeticus Narcissus. The flowers are pure white, double, and very sweet scented. A beautiful variety for the open ground, but it cannot be forced. Flowers late. Dozen, Ioc (by mail I2c); roo, $50 \mathrm{c}$.

Von Sion-The well-known double yellow Daffodil. The flowers are large, double and of a good bright yellow. Good for forcing as well as the open ground. Extra large bulbs. Each $3 \mathrm{c}$; dozen, $25 \mathrm{c}$ (by mail $30 \mathrm{c}$ ); $100, \$ \mathrm{I} .75 ; 500$, $\$ 8.00$.

\section{POLYANTHUS NARCISSUS.}

The Polyanthus varieties produce a great many small flowers on each stem, and as they flower early they are valuable for forcing. The flowers are deliciously sweet scented and are very ornamental. When planted in the open ground they require some protection in the north. A good covering of leaves will protect them perfectly.

Paper White Grandiflora-Pure white flowers of large size for this class. Flowers very early and can be had in bloom by Christmas. Not suitable for out door planting. First quality bulbs. 3c each; doz. 3 oc (by mail 35c); 50, \$1.00.

Grand Monarque -Large white flowers with light yellow centers. Very handsome and easily grown. Can be raised in water with nothing but a few pebbles in the bottom of the dish. Each, 6c; doz. 45c (by mail, 5oc); 50, $\$ 2.00$.

Newton--Flowers bright yellow with orange centers. Very handsome. Each, 6c; doz. $45 \mathrm{c}$ (by mail, 5oc) 50, $\$ 2.00$. 


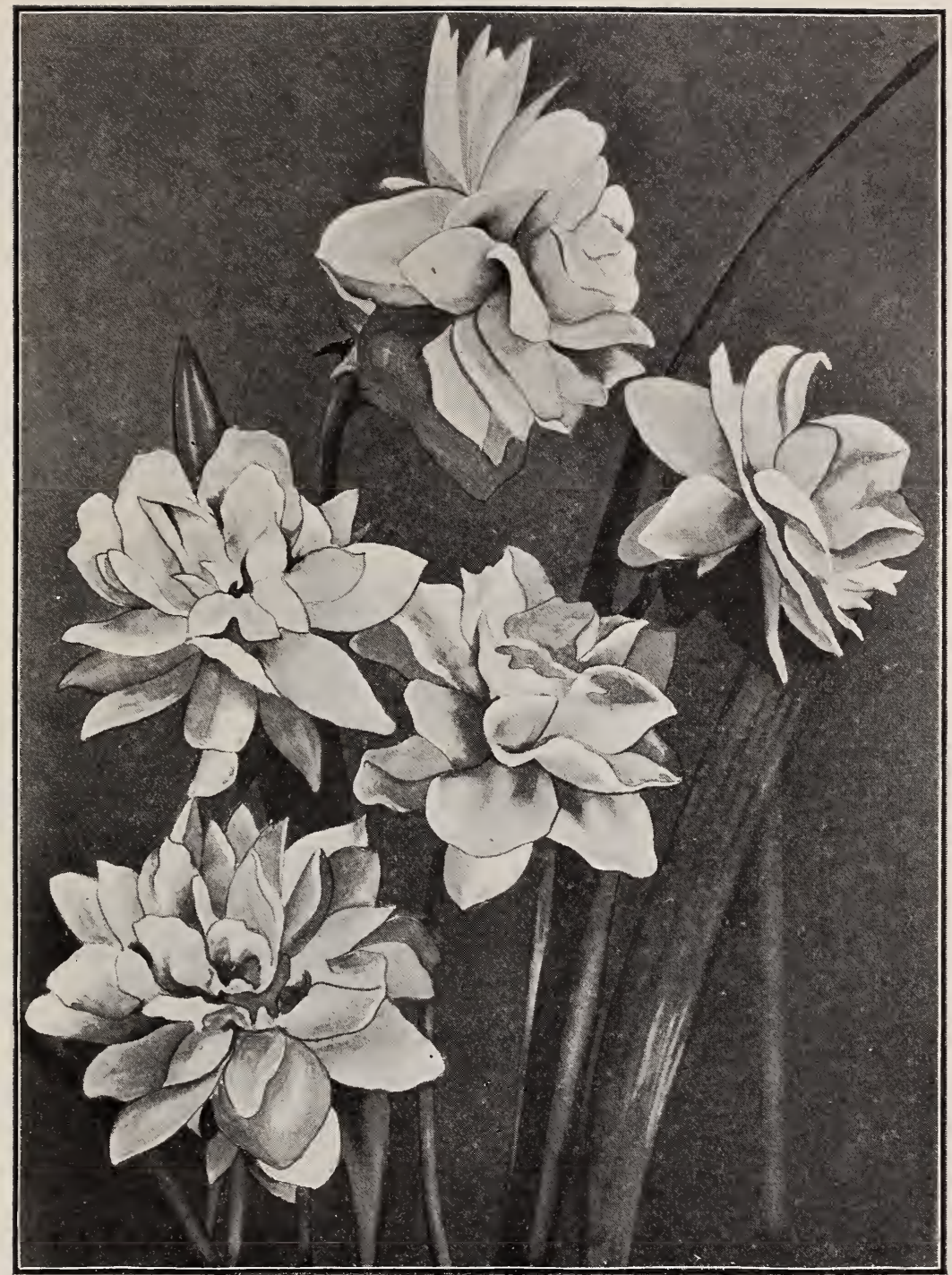

Narcissus Orange Phoenix.

White Pearl-The best pure white Polyanthus variety for open ground and excellent for forcing. Each, 6c; doz. 5oc (by mail, 55c) 50, $\$ 2.25$.

Chinese Sacred Narcissus. The much advertised "Chinese . Sacred Lily." This is a variety of Narcissus that blooms very quickly after the bulbs are started and is often grown in bowls of water with a few pebbles in the bottom to hold the bulbs in place. The flowers are white with a large golden yellow cup in the center. Large bulbs, Ioc each; dozen, $\$$ I.0o (by mail, $\$$ I.10).

\section{SCILLA.}

Scilla Siberica is a pretty little blue flower that blooms with the Crocus, and is very attractive when grown in clumps in connection with these and Snowdrops. The plant is dwarf and produces sprays of deep blue flowers. Perfectly hardy and will last for years. Dozen, $20 \mathrm{c}$ (by mail, 23c); 100, \$1.40. 


\section{CHIONODOXA (Glory of the Snow).}

This very pretty spring flower is not grown as much as it should be. The flowers come almost as soon as the snow is gone, and their bright colors and graceful form make them very attractive. The flowers are bright blue with white centers, and grow in clusters on the stem. When planted in a row or in masses with the bulbs close together the effect is charming. The bulbs are perfectly hardy.

Luciliae-The most popular variety having lilac-blue flowers with white centers. Dozen, 20c (by mail 23c); roo, \$1.ro.

Gigintea-An improved large flowering variety with large flowers and longer spikes than the old kind. Dozen, $25 \mathrm{C}$ (by mail $28 \mathrm{c}$ ); roo, $\$ \mathrm{I} .50$.

\section{MILLA or TRITELEIA.}

Milla Uniflora or "Star Flower" is little known, but deserves more attention. The flowers are small standing on stems 6 to 8 inches long and are of a delicate porcelain blue. Should be planted in clumps on moist ground where it will not be disturbed. The handsome foliage will cover the ground and produce a great many flowers early in the spring. This flower can also be grown in the house by planting 5 or 6 bulbs in a 6 inch pot or box. Dozen roc (by mail r 2 ) ; roo, 50c; 500, $\$ 2.00$.

\section{HARDY PERENNIAL PLANTS}

\section{FOR FALL PLANTING.}

The best time to set out perennial plants is in the fall-from the middle of October until the ground freezes. If set out at this time they will flower much earlier and more profusely than if set out in the spring.

Nothing that we know of in the way of ornamental plants will give so much satisfaction with so little trouble and expense as hardy perennial plants if well selected. The first cost of the plants is small and it is the only expense as they will in most cases take care of themselves after once established with only slight care in the way of removing weeds, etc.

We offer a few of the most desirable kinds and varieties for general use.

The plants will not be ready to transplant before the middle of October but orders may be sent at any time and the plants will be forwarded when they are ready.

All these plants are sent by express at the purchasers expense, except where noted. Bulbs and plants can be sent together by express with little or no extra expense.

\section{ASTERS (Michaelmas Daisy).}

The hardy asters are very graceful and decorative plants, blooming in the fall when other flowers are scarce. The plants grow 3 to 4 feet tall and are covered with their delicate and pretty flowers for a long time. We have selected a few of the most desirable varieties.

Nova Anglaea, (New England Asters)-Flowers of bluish-purple and produced in great masses. 4 feet tall.

Nova Anglaea Rosea-Flowers of a bright rosy-pink and very large and abundant. This is one of the very handsomest varieties known and should be largely planted. Purity-Pure thite, large and graceful, 3 feet tall.

Acris-A charming sháde of blue. 4 feet tafl. Strong field grown plant, r2c each, (by mail I5C); dozen $\$ 1.20$.

\section{DELPHINIUM or LARKSPUR.}

The new and improved varieties of Larkspur have brought this flower again into great popularity. They are very handsome when grown in the corner of a fence or by the side of the house. They are easily grown and flower from June until frost.

Kelway's Hybrids-These new varieties of English Delphinium are by far the handsomest grown. The flowers are large and of delicate coloring. Some of the plants grow tall, but many are semi-dwarf and do not need staking. We offer a mixture of the best varieties and colors. Strong plants, per dozen, $\$ 1.50 ; 50$ plants, $\$ 5.00$.

Farmosum-The old and popular bright blue Larkspur. The plant is of vigorous growth, and produces long spikes of flowers of an intense blue color. Dozen, \$1.25; 50 plants, $\$ 4.00$. 


\section{HOLLYHOCKS.}

For planting along a fence or in clumps by the side of the house or in any corner of the garden there is nothing handsomer than Hollyhocks. They will grow and thrive among grass and weeds and will take care of themselves when once established. We offer strong plants that will flower profusely next summer if set out in October.

Double-In separate colors, red, white, pink and yellow. Each, roc; dozen, \$1.oo; $50, \$ 3.50$.

Alleghany-A new class of Hollyhocks with semi-double flowers of great size and beauty. The edges of the flowers are fringed and ruffled, which adds greatly to their beauty.

Mixed colors, each, I2c; dozen, \$1.20; 50, \$4.00.

\section{IRIS.}

(See Photograph on Cover.)

There are numerous kinds of Iris of which the German and Japanese varieties are by far the handsomest and most desirable. The German varieties are smaller than the Japanese but flower a month earlier and produce a greater profusion of bloom. It is well therefore to plant some of each of these two kinds, as by this means Iris may be had in flower for three months.

These varieties are perfectly hardy and will grow in any good garden soil. They prefer a moist and sunny situation and will grow in very wet land. If grown in dry soil the size of the flowers will be much improved by liberal watering in dry weather.

October is the best time to set out Iris. They will then bloom the following spring and summer and will increase in size and profusion of bloom for many years. The plants should be set at least a foot apart and finer flowers are produced if they are given more room.

\section{JAPANESE IRIS. (Iris Kaempferi.)}

It is impossible to give a description that will do justice to the beauty and rich and varied coloring of these charming flowers. The flowers are of immense size, often Io inches across, with broad, flat petals that droop at the edges. Their coloring is exquisite, ranging from pure white to deep blue and purple, many flowers being veined and striped with white, yellow and orange, with a blotch of orange at the base of each petal. The flowers are produced on long stems and are very useful as cut flowers.

Plants set out this fall will bloom from the middle of June through July. The plants are perfectly hardy and need no protection in winter. There are hundreds of varieties, many with impossible Japanese names, so we do not attempt to give the names and descriptions of each kind, but we have selected a dozen of the largest and most beautiful varieties, possessing a great range of colors and markings, such as pure white (with orange center), azure blue, white veined with blue, deep purple, rich maroon, violet blue, white edged with purple, royal purple, and other combinations of colors. There are no finer varieties of Iris than these.

Strong plants, I5c each; I each of 6 varieties, $75 \mathrm{c}$; 1 each of 12 varieties, $\$ 1.35 ; 2$ each of 12 kinds, $\$ 2.50$. (These plants are too large to be sent by mail.)

\section{GERMAN IRIS.}

The flowers are somewhat smaller than the Japanese kinds and of diferent form, the center petals being long and upright, giving the flowers a peculiar appearance, much like

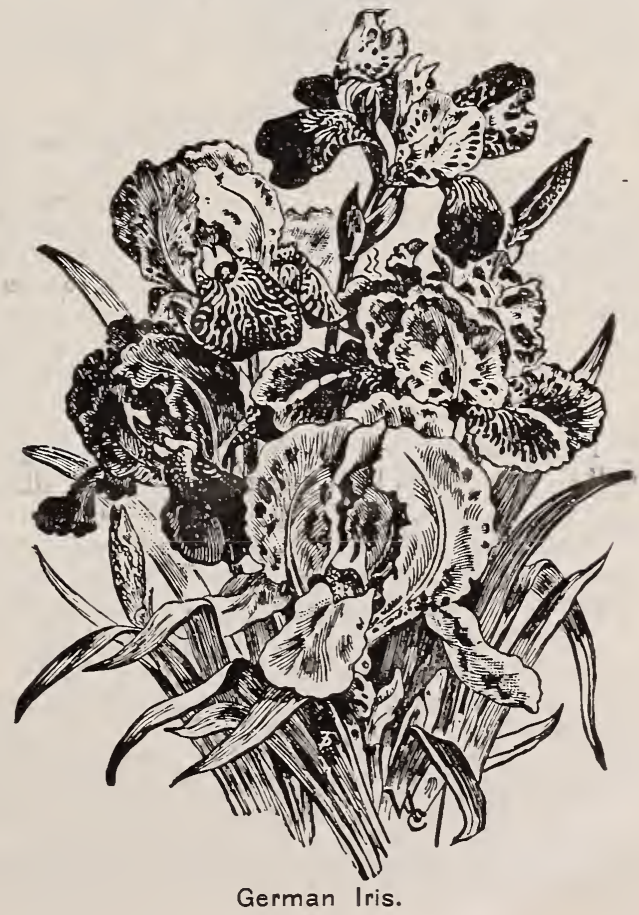


an orchid which they rival in variety and delicacy of coloring. They are hardy, and will do well in any good garden soil, producing a great profusion of bloom in May and June. We offer six very beautiful named varieties embracing the most charming colors and markings known to this class of Iris. Strong plants roc each; I each of six kinds, 5oc; doz. 80c; 2 doz. \$1.50.

Mixed Varieties-These are composed of a great many varieties without names, or the names of which have been lost. Doz, 50c; 30 plants $\$ 1.00$.

\section{CAMPANULA. (Canterbury Bells)}

Media-The true Canterbury Bells. Both blue and white flowers. Strong plants, roc each; dozen, \$r.oo.

Persicaefolia Grandiflora-A charming variety with light porcelain blue flowers in great profusion. Plant of graceful branching habit. Strong plants, I2c each; doz. $\$ \mathrm{I} .25$ (These plants require some protection in winter in the north.)

\section{GAILLARDIA. (Blanket Flower)}

The single Gaillardia grandiflora resembles a very large brilliantly colored daisy and is a very handsome flower either in the garden or for cutting. The flowers are often 3 or 4 inches across and are produced on long stems, and their coloring is very gorgeous, being composed of deep red and yellow in bands and markings. Perfectly hardy and will last for years. Strong plants, roc each; dozen $75 \mathrm{c}$; (by mail, 85c.)

\section{DIGITALIS. (Foxglove)}

Gloxenardis-An improved strain of Foxglove with long spikes of flowers ranging in color from white to deep pink, much handsomer than the old spotted kinds. Strong clumps, I5c each; dozen, \$r.25.

\section{PYRETHRUM, or "Painted Daisy."}

The single Pyrethrum Roseum is a charming flower that should be better known. The flowers to all appearances are colored field Daisies or Marguerites. The colors range from deep red to light pink, and as the flowers are often 4 in. across with bright yellow centers they are very unique and attractive. The flowers grow on long stems which stand well above the plants and are very handsome as cut flowers. The plants are perfectly hardy and will bloom for many years. They flower in May and June. Plants, doz. $75 \mathrm{c}$; (by mail $85 \mathrm{c}$.)

\section{STOKESEA CYANEA. (Cornflower Aster)}

A new hardy flowering plant that is attracting a great deal of favorable attention. The plants grow $\mathrm{I} I / 2$ to $2 \mathrm{ft}$. tall and flower all summer. The flowers are often 4 in. across, lavender blue in color and of handsome and graceful form much resembling a large Centaurea or double Bachelor's Button. The plants are hardy and should be planted where they can be left for a number of years as they are much handsomer the second season. Plants roc each; doz. 5oc; (by mail 55c.)

\section{PERENNIAL PHLOX.}

The new and improved varieties of these old fashioned flowers are among the handsomest of the hardy flowering plants. They flower continuously from July to November and present a gorgeous display of color hardly equalled by any other plant. Plants set out this fall will bloom ln great profusion next summer. They are perfectly hardy and need no protection.

There are many varieties but wc offer only a few of the very best, embracing the following colors: Pure white, bright scarlet, rose pink and salmon pink. Strong, field grown plants, I2c. each; \$I.ro per doz. by express.

\section{LILY OF THE VALLEY.}

This flower is too well known to need description. It thrives best in partial shade and moist soil. The best and quickest way to start a bed is to set out large clumps of roots in the fall. The little "pips" usually sold do not amount to much when set out in the open ground until they have grown for two or three years.

We can furnish large clumps of roots to be sent by express at purchaser's expense at $25 \mathrm{c}$ each; $\$ 2.50$ per doz.

These roots will flower abundantly next spring. They will not be ready for shipment until October I 5 th. 


\section{POTTED \\ STRAWBERRY PLANTS.}

A Crop Next Year. By using potted plants and setting them out in August or September, a good crop of strawberries can be raised next June. Ordinarily layer plants, such as are used for spring planting, if set out in the fall will not produce a crop next season. Potted plants are much more expensive, but a whole year can be gained by their use and they produce very fine, large berries.

The plants are grown in pots, and as the roots fill the pots, forming a ball, they can be transplanted without checking their growth in the least, so that they will form strong fruit buds for next spring. If ordinary layer plants are transplanted in the fall they are so checked that they will not form any fruit buds and so fail to produce a crop.

We have grown some fine plants of a few of the best varieties for home use. All of these produce berries of delicious flavor and large size, and are especially desirable for those who want berries of fine quality.

The plants will be ready to ship about August 25th, and can be set out any time after that date; but the best time to set them is in August and first part of September. They should be set in rows 2 feet apart and a foot apart in the row. These plants cannot be sent by mail. They are sent by express at purchaser's expense.



Senator Dunlop-This is not only an early strawberry but it keeps on bearing for a long time. The berries are large, deep red and of fine quality, being sweet and possessing a delicious flavor. The plants produce large crops and are strong and healthy.

Brandywine-This variety has been grown for a good many years but is still one of the very best kind known. The berries are large, smooth and even in shape, firm and of the very best quality. It is a medium to late variety and produces very large crops on strong, healthy vines.

Gandy-This is one of the best late varieties and will prolong the season a week after other kinds are gone. The berries are very large and also of fine quality, a combination which is exceptional.

PRICE of Potted Plants-Dozen, 50c; 50, \$1.35; I00, \$2.50. Plants carefully packed and their delivery in good condition is guaranteed.

\section{COLLECTIONS OF STRAWBERRIES.}

COLLECTION No. 1-We will send a collection of roo potted plants composed of one-third each Senator Dunlap (early), Brandyruine (medium), and Gandy (late), for $\$ 2.50$.

COLLECTION No. 2-This collection is composed of 150 plants, 50 each of the above three kinds, which will make a nice bearing bed next summer. Price $\$ 3.60$.

Potted strawberry plants cannot be sent by mail without washing all the earth off the roots which destroys their usefulness for fruiting the following summer. The plants are packed so as to preserve the ball of earth around the roots and are sent by express at the expense of the purchaser . 


\section{WINTER WHEAT.}

We have a lot of very choice seed wheat grown on our own and neighboring farms, which is far superior to the wheat usually sown as it is pure and clear, free from rye or chess, and the varieties we offer are the best we know of. We have taken a good deal of pains to get all the facts possible about different varieties of wheat and we have come to the conclusion that for a white wheat there is nothing better than "International No. 6" and Dawsons's Golden Chaff. For a red wheat we have chosen "Harvest King," as it seems to give the best satisfaction wherever grown. There are a good many varieties for which great claims are made, but we cannot find that they give as good yields one year with another as the above named kinds.

Our seed wheat will be ready to ship about August I5th. It is thoroughly cleaned



International No. 6 Wheat. (Photograph)

with a special seed cleaner which makes it much better than it can be made with an ordinary fanning mill.

Prices are for wheat delivered on cars at Rochester, where we can ship by N. Y. Central, Erie, Lehigh Valley, Pennsylvania, B. R. \& P. and Rome, Watertown \& Ogdenburg R. R.

BAGS-We ship in new cotton grain bags for which we charge just what they cost us in large lots. They are worth every cent they cost. Bags will hold $21 / 2$ bushels. When ordering please remit for enough bags to hold the quantity ordered. If the bags are not paid for we will have to send enough less wheat to cover the cost of the necessary bags.

New 16 ounce cotton grain bags, $17 c$ each. Will hold $2 \frac{1}{2}$ bushels. 


\section{INTERNATIONAL No. 6 WHEAT.}

This wheat has been raised in this neighborhood for a good many years and has proved itself to be the very best white wheat grown here, both in quality and yield. It has a rather short, stiff straw and square or "clubbed", head, always brimful of large, plump, white kernels. This wheat always agreeably surprises the grower in the way it turns out grain. A field will look as though it would yield perhaps 30 bu. per acre, but when you come to thresh it you find you have 40 bu. or more per acre. Some kinds make a larger growth of straw and look as though they would yield more, but the "No. 6 " comes out ahead at the threshing machine every time.

The photograph reproduced here gives a good idea of the head of this wheat. The straw is of medium height and very stiff, so that it does not lodge. The grain is of good size, plump and hard, and makes the best of winter wheat flour.

Price-\$1.25 per bu. Bags I7c each extra. Not less than I bu. will be sold. Sample

sent for $\approx \mathrm{c}$ stamp.

\section{HARVEST KING WHEAT.}

This is a grand variety of Longberry Red Wheat. It is a bald or beardless kind and has very long heads, tall, stiff straw and large, plump berry that is hard and of the best quality. Red wheat usually commands the highest price, and the "Harvest King" is the best red variety we have found. It yields heavy crops, does not blight or rust and is not liable to lodge. It has a close, stiff white chaff, so that it does not shell easily and stands wet weather well without sprouting.

We doubt whether there is any red wheat that will yield larger crops of first class grain than the Harvest King.

Price- $\$$ I.40 per bu. Bags I 7 c each extra (hold $2 \frac{1}{2}$ bu.).

\section{DAWSON'S GOLDEN CHAFF WHEAT.}

This variety has gained great popularity in the last few years on account of the large yields produced, and its hardiness and vigor and especially on account of its freedom from the attacks of the Hessian fly. Where the fly is troublesome there is no better kind to raise than this. For some reason the fly will leave the Golden Chaff wheat alone while other kinds in the same or adjoning fields are destroyed by it.

The plant is of great vigor and will succeed on almost any soil. The heads are quite long, bald and usually well filled with large amber colored grain of good quality.

We have heard of very large yields from this wheat and have had good success with it on our own farm. Yields of 38 to 45 bushels per acre are not unusual.

We offer some first-class pure seed.

Price-\$1.30 per bu. Bags, I7c each extra.

SPECIAL PRICES will be quoted by letter on lots of 20 bushels or more. Samples will be mailed on receipt of 2c stamp. In writing for prices please state what variety is wanted and about what quantity will be required.

\section{WINTER RYE.}

We have a limited quantity of what is called "Mammoth White Winter" Rye. We do not know that there is much difference between this and the rye that is commonly grown, but it is certainly good rye with large berry and very long straw and long heads. Rye straw always brings high prices in city markets and is a profitable crop. If it can be threshed without disturbing the bundles it often sells as high as $\$ 25.00$ per ton.

Rye can be sown here as late as the middle of October. It is a good "catch crop" to sow after late potatoes.

Price-Choice, clean seed, $\$ \mathbf{1 . 0 0}$ per bu. Bags, i7c each extra.

\section{SEED POTATOES.} seed :

We have the following varieties of potatoes growing on our own farm especially for

Early Varieties-Irish Cobbler, Early May, Early Trumbull, Bovee, Early Ohio, Clark's No. I, Early Michigan.

Late Varieties-Washington, Vermont Gold Coin, Harris' Snowball (new).

We should be glad to quote special prices for fall delivery on any quantities desired. The potatoes will be ready to ship about November ist.

Our Northern grown potatoes do especially well in the South, and it will pay those living south of Pennsylvania to buy in the fall so as to have the potatoes on hand for early planting in the spring. 


\section{NORTHERN SPY APPLES.}

We have for many years raised large quantities of very fine Northern Spy apples but have always sold them to dealers. This year we have decided to offer our crop direct to the consumers in such quantities as they may require.

We think there are many people who would be glad to take advantage of this opportunity to get choice apples direct from the trees without having passed through several dealer's hands.

The Northern Spy Apple, as is well known, is one of the very best apples grown either for eating or for cooking. We often sell a few bushels of Spy apples to our neighbors who have hundreds of barrels of Baldwins, Greenings and other kinds on their own trees, simply because they are of so much better quality than any apples they have. They sell the Baldwins, etc., for some one else to use and buy Northern Spys for themselves.

There is no apple known that varies so much in quantity as the Spy. There is no apple raised that is as fine as a well grown Spy, and there are few poorer than a poor one. Too many of the Northern Spys sold are carelessly grown, small, green and poor. They are hard apples to raise in perfection, but they are well worth the trouble and expense necessary to do so. We have two large orchards composed of nothing but Northern Spys. These orchards are given a great deal of care and we have long had the reputation of producing as fine Northern Spys as any in the county, and there are no finer apples in the world than those raised in Western New York along Lake Ontario.

Grading and Packing. Our apples are picked in burlap lined baskets to prevent bruising. When a basket is filled it is emptied on a canvas table in the orchard where the apples are sorted and packed in barrels and boxes without ever touching the ground. For this reason they are cleaner and keep better than apples handled in the ordinary way.

Two Grades. We put up our apples in two grades, both fine fruit. All

"Extra Selected." This grade is composed of the largest, handsomest and best colored apples. This quality of fruit cannot be obtained on the market (except possibly in New York or Boston at very high prices). To those who want the finest apples obtainable we recommend this grade. They are magnificent apples and will be found of the finest flavor and highest quality for any purpose. Each apple is wrapped in tissue paper, which keeps them clean and preserves their delicate flavor.

No. 1 Apples. This grade is composed of good, sound apples of good size and first class quality, but not quite as fine as the above. This grade is much superior to the No. I apple usually sold. They will keep well and will be found excellent for cooking or for any other purpose.

Price. For orders received before October $15^{t h}$ (not later) so we can fill them when picking, we will make the following prices:

"Extra Selected" Grade-Box holding I bushel, each apple wrapped in

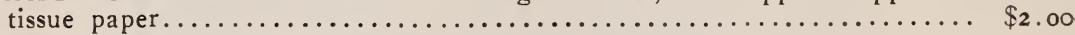

Barrel, standard size, cushion heads to prevent bruising, and each apple wrapped in tissue paper.............................. $\quad 45$

No. 1. Apples-Packed in barrels only. Each barrel has a cushion head and

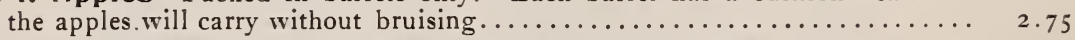

Freight Charges. The purchaser is to pay freight charges, which will amount to about $35 \mathrm{c}$ per barrel to any point in this State, Pennsylvania, New Jersey, New England and Ohio. To other places further off the freight would be slightly more. The freight on a box would be the same as on a barrel, but three or four boxes could be sent with little or no extra expense for freight.

Special Prices will be quoted on lots of five barrels or more, freight paid to purchaser's station.

Keeping Apples. Northern Spy apples, if stored in a cold place, will in an ordinary cellar until the middle of April. The apples should be kept at a temperature as near $32^{\circ}$ as possible. They will stand a temperature $5^{\circ}$ or $6^{\circ}$ below freezing $\left(26^{\circ}\right.$ to $27^{\circ}$ ) without injury. If the cellar is warm the apples will not keep so long. Those who have a cool cellar could safely put in three or four barrels of apples, which would last all winter and there would be little loss from rotting.

Date of Shipping. We do not pick apples until after the middle of October, so all shipments will have to be made after that date. The best time to ship is during November. Orders may be sent at any time and the apples will be shipped when they are ready. 
Terms. Orders will be booked at any time before October $15^{\text {th, }}$ and the money can be sent either with the order or when the apples are to be shipped. The usual terms of payment will be extended to those of our customers who are well known to us.

Order before October 15th. We cannot agree to fill orders for apples received after this date. If for any reason orders are delayed until later, we will fill them if we can, but we urge all who want to be sure of getting first class apples to send their orders in as early as possible. The crop is small this year but the fruit is very fine.

\section{PERUVIAN GUANO.}

\section{A Splendid Fertilizer for Wheat.}

The wheat plant, as is well known, requires for its best development a liberal supply of available phosphoric acid and a moderate amount of nitrogen in the soil. Peruvian Guano contains just these elements in the right proportion for wheat.

The genuine Peruvian Guano is composed of the droppings of millions of sea birds, which swarm on the rocky islands in the rainless regions along the Pacific coast of South America. These birds live on fish, and this guano contains the rotted remains of fish as well as the birds themselves, and is therefore rich in nitrogen and phosphoric acid. Owing to the thorough decomposition of the material, which has taken place during the many years which it has taken to accumulate, the fertilizing elements are in a very quickly available form.

The material we offer is in the form of a fine, dry brown powder, and analyzes about as follows :

Ammonia (Nitrogen) .................

Potash................................. "

Phosphoric Acid..................

The composition of this material varies somewhat, and each cargo is analyzed when it arrives at New York, and the bags are marked accordingly. The analysis, therefore, may vary slightly from above figures.

About 12 per cent. of phosphoric acid is immediately available while the rest is in such a finely powdered form that it quickly becomes available in the soil as does finely ground bone.

The guano is not treated with acids or any other substance, and is in its natural condition except that it is screened.

Price of Peruvian Guano.-We offer this material in two grades-unscreened or in its natural state, and screened. The unscreened contains some lumps and small pieces of bone which interfere with drilling, but it is all right to use where it is applied by hand. The screened is free from all hard lumps and is very fine, so that it will drill perfectly. To be shipped from New York in $200 \mathrm{lb}$. bags delivered on cars :

Unscreened, single bag..........200 lbs., $\$ 3.50 \ldots \ldots$. Ton $\$ 30.00$

Screened, " $\ldots \ldots \ldots \ldots$ " " $3.75 \ldots \ldots$ " 32.50

To be shipped from here or Rochester (screened):

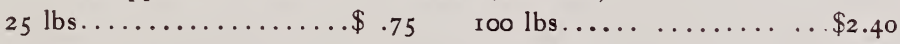

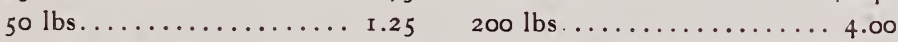

Amount to Use.-As Guano contains more than twice as much phosphoric acid and nitrogen as does the average " phosphate," used for wheat, it is necessary to use only half as much per acre to get the same results. If 200 pounds of guano is used per acre, it will be equal to using 400 pounds of a fertilizer containing ro per cent. phosphoric acid and $\mathrm{I} / 2$ to 2 per cent. ammonia. This is rather more than the average farmer uses on wheat, but it is none too much, and it will pay better than a smaller quantity. We would recommend the use of 250 pounds of guano per acre, but of course a smaller quantity can be employed with good results. 


\section{WHITE WYANDOTTES.}

We have been breeding White Wyandottes for a good many years, and we have kept constantly improving our stock until now we think we have a very fine strain, possessing all the good qualities that go to



their stock. make up the best fowls for practical purposes as well as beauty of appearance.

This breed is now almost universally conceded to be the best for a general purpose fowl. They combine large size and the best of table qualities with a great capacity for producing eggs, especially in winter when eggs are most desired. In addition to this they are very handsome, having snow white plumage, bright yellow legs and neat rose combs.

Those who have common mixed fowls will do well to use nothing but White Wyandotte cocks, as in so doing they can greatly improve

\section{Reduced Prices for Fall Delivery.}

We have some very fine young stock this season and can make the following low prices for delivery this fall (November and December).

Good Cockerels-Large, strong and vigorous, suitable for crossing with other breeds to improve the stock .........\$1.50 each

Extra Fine Cockerels-Carefully selected for "fancy points" such as very white plumage, perfect shaped comb, blocky shape, etc. These cockerels are very fine, being as good as can be obtained of many breeders for $\$ 8.00$ to $\$ 10.00$ each ........... \$4.00 each

Pullets-Large and very fine \$I.25 each. Good ones, \$I.00 each.

The birds will be carefully crated in light wooden crates which insures safety and low express charges.

\section{JOSEPH HARRIS CO. SEED GROWERS}

